\title{
BEING A CETRA STUDENT: A CRITICAL ACCOUNT OF THE 2009 SUMMER SCHOOL
}

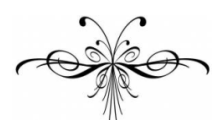

ALICE LEAL

\begin{abstract}
The present paper is a short critical account of my experience as a CETRA Summer School student in 2009. In addition to mentioning practical information about the application process, funding possibilities, visas and insurance, I shall also draw an overview of the 20 years CETRA and its Summer School have been in existence. Furthermore, I will include a description of the routine at the Summer School and, finally - and perhaps most importantly - I will comment on the Summer School's seminar, lectures, tutorials and students' presentations. The main aim of this paper is not only to provide an overview of this prestigious event in Translation Studies, but also to encourage other students to take part.
\end{abstract}

Resumo

O presente trabalho é uma descrição da minha experiência como aluna na CETRA Summer School do ano de 2009. Além de fornecer informações práticas acerca do processo de inscrição, possibilidades de bolsa, vistos e seguros, o trabalho também incluirá um breve panorama desses 20 anos de existência do CETRA e da sua Summer School. Ademais, uma descrição da rotina diária na Summer School será feita e, por fim, os seminários, palestras, tutoriais e apresentações dos alunos serão comentados em mais detalhe - constituindo, a meu ver, a parte mais importante do presente trabalho. O principal objetivo deste texto é não só fornecer um panorama deste que é um dos eventos mais prestigiosos nos Estudos da Tradução, mas também motivar outros estudantes a participar. 
C ETRA, or Centre for Translation Studies, is one of the most traditional research programmes in Translation Studies, which hosts one of the most prestigious events in our area, namely the CETRA Doctoral Summer School. Having had the privilege to be one of the 2009 CETRA students, I intend to describe the experience in this short paper, as well as to provide practical information for potential future applicants. The present paper shall be divided into three sections, the first two of which being more general and shorter, and the third one being more personal, and hence longer. In the first section of the paper, I will very briefly describe the background of both CETRA and its famous Doctoral Summer School, detailing the programme and some of the main features of the latter. In section 2, I will provide some practical information on the application process, visa, fees and some of the funding possibilities. Finally, in section 3, I will present an overview of the 2009 edition of the Summer School, highlighting the points that seem more conspicuous - at least in my opinion - to a largely Brazilian audience. This section will also include some criticism and personal comments. Needless to say, it would be impossible to provide a complete account of all lectures, seminars and presentations, so whatever comments or criticism I make must obviously be taken as biased fragments of a larger whole ${ }^{1}$. For reasons of style and length I will not constantly write "in my opinion" or "from my point of view", hence I will take it for granted that the reader knows that this paper consists of subjective opinions. These three sections will be followed by a succinct conclusion and the respective references. As my paper is clearly not a scientific article as such, but rather a critical account of my experience at the 2009 CETRA Summer School, I would like to warn the reader not to expect long quotations and lengthy references.

Finally, I would like to thank my colleague Gustavo Althoff, for having asked me to write this paper for Scientia Traductionis; EST (European Society for Translation Studies), for having given me the Summer School grant; CETRA and all their 2009 staff, for the unique experience as their student; and finally my dear friends Silvânia Carvalho and Philippe Humblé, for having received me in their home in Bertem, Belgium.

\section{CETRA: background and overview ${ }^{2}$}

The Centre for Translation Studies of the University of Leuven (CETRA) was founded in 1989 by José Lambert as a research programme in Translation Studies. Having been supported by a number of different sponsors during these two decades of existence, CETRA is now part of the integrated Faculty

\footnotetext{
${ }^{1}$ For a different account of the same event, please check EST Newsletter no. 35 (November 2009).

${ }^{2}$ The information presented here was largely taken from the CETRA's website http://www.kuleuven.be/cetra/index/index.html
} 
of Arts at the University of Leuven (Katholieke Universiteit Leuven, henceforth K.U. Leuven). At the time of writing, Reine Meylaerts is the Director of CETRA, and José Lambert is its Honorary President. The other K.U.Leuven members are Theo D'Haen, Lieven D'hulst, Michèle Goyens and Nicole Delbecque. The centre also counts on two members from the Hogeschool Universiteit Brussel, Ludo Teeuwen and Elke Brems, two members from the Lessius University College, Frieda Steurs and Luc Van Doorslaer, as well as on Dirk Delabastita, from the FUNDP Namur.

In addition to offering a $\mathrm{PhD}$ programme that attracts young scholars from all over the world and promotes a dynamic exchange of teachers and students within the framework of PhD education, CETRA also organises and hosts a yearly Doctoral Summer School, which indeed is the main topic of the present paper. Furthermore, it promotes different scholarly events of international interest in collaboration with other universities ${ }^{3}$.

The first CETRA Summer School was held in 1989, under the supervision of José Lambert. The idea was to gather talented PhD students at K.U. Leuven for two weeks to encourage the exchange of ideas amongst young scholars and professors from a number of different countries. The CETRA Summer School has now been a success for twenty years, attracting participants - both students and professors - who work in various areas within Translation and Interpreting Studies.

The two-week Doctoral Summer School consists of five main activities, as follows: lectures held by the CETRA Professor ${ }^{4}$ (who changes every year - see below); seminars given by CETRA's teaching staff (which also changes every year); tutorials (or individual sessions between students and professors); students' presentations of their research; and finally, students' publications. The daily routine of CETRA students and teachers begins with collective breakfast between 8 and 9 AM at the university canteen. Between 9 and 11 students can either do library work or have tutorials with the CETRA teachers. Because tutorials have to be planned in advance, CETRA organisers make the professors' schedule available beforehand, so that students can make appointments. At 11 o'clock members of the CETRA teaching staff hold one or one and a half hour seminars on numerous topics. Collective lunch follows from around 1 to $2 \mathrm{PM}$, again at the university canteen. After that, students can once again either do library work or have tutorials until about 5:30, when the evening lecture held by the CETRA Professor begins. This final lecture also lasts for about one or one and a half hour.

Once a week - i.e. twice over the two weeks - there is a collective dinner as well, usually served in one of the finest restaurants in the centre of Leuven ("De Trobadour" - http://www.troubadour.be/). The dinner gives students and teachers the chance to meet informally, away from the university setting.

\footnotetext{
${ }^{3}$ For more information, please check http://www.kuleuven.be/cetra/events/events.html.

${ }^{4}$ The CETRA Professor is the main professor of the Doctoral Summer School. S/he holds the most lectures and takes part in all events. Naturally, the choice of CETRA Professor ends up strongly influencing the range of topics discussed throughout the event. In the present paper, I will refer to the CETRA Professor as "professor" and to CETRA teaching staff as "teachers", even though these teachers are also professors at their home universities.
} 
The three last days of the Summer School are devoted to students' presentations of their research projects. This way, instead of having library work, tutorials and an evening lecture, students and teachers gather to discuss each student's project. Sessions last for about 30 minutes, the presentation itself taking up to 20 minutes and the remaining time being dedicated to feedback and discussion. As the tutorials, all presentations must be scheduled beforehand between 9 and 11, and then between 2 and 5 or 5:30 PM.

The list of all CETRA Professors offers a hint of how multicultural and multifaceted the Summer School is (as, by the way, do the lists of CETRA teaching staff and CETRA participants5): Gideon Toury (Tel Aviv, 1989), Hans Vermeer (Heidelberg, 1990), Susan Bassnett (Warwick, 1991), Albrecht Neubert (Leipzig, 1992), Daniel Gile (Paris, 1993), Mary Snell-Hornby (Vienna, 1994), †André Lefevere (Austin, 1995), Anthony Pym (Tarragona, 1996), Yves Gambier (Turku, 1997), Lawrence Venuti (Philadelphia, 1998), Andrew Chesterman (Helsinki, 1999), Christiane Nord (Magdeburg, 2000), Mona Baker (Manchester, 2001), Maria Tymoczko (Amherst, Massachusetts, 2002), Ian Mason (Edinburgh, 2003), Michael Cronin (Dublin, 2004), †Daniel Simeoni (Toronto, 2005), Harish Trivedi (Delhi, 2006), Miriam Shlesinger (Tel Aviv, 2007), Kirsten Malmkjaer (London, 2008), Martha Cheung (Hong Kong, 2009). In 2010, the CETRA professor will be Sherry Simon, from Concordia University, Canada.

After the end of the Summer School, all students can publish a paper which does not necessarily have to coincide with the topic of the student's presentation - on the CETRA webpage (www.kuleuven.be/cetra/papers/papers.html). Students usually have up to four months to submit a preliminary version of their papers, which then might or might not be accepted by the editorial board. Selected papers might need adjustments before publication, which normally takes place within a year after the Doctoral Summer School.

Whereas on the one hand CETRA Professors and teaching staff tend to be very experienced, renowned researchers, most CETRA students are, on the other hand, in the initial stages of their research, which is both positive and negative. It is positive because research at initial stages is easier to adapt, to change, and the amount and variety of feedback students normally get will certainly lead to a number of changes in their projects. Nevertheless, this is also negative, since many students have very little knowledge of Translation Studies, many coming from different areas and taking their first deep plunge into TS. Undoubtedly, this makes certain discussions significantly less interesting or even non-existent - we are all familiar with that uncomfortable silence that fills the room at the end of a lecture or seminar.

All in all, the Summer School has unquestionably been extremely successful in these first two decades, and its future looks bright as the discipline advances into yet another decade.

\footnotetext{
${ }^{5}$ For more on this, please refer to section 3 below or check: http://www.kuleuven.be/cetra/alumni/alumni.html, and: http://www.kuleuven.be/cetra/staff/staff.html.
} 


\section{Practical information: application, fees, visa, insurance}

In order to become a CETRA student, the first step is to apply for a position. Application usually takes place between early January and late May, but deadlines are fairly flexible (see section 3 below). The application consists of a motivation letter, a CV and a registration form, which in turn can be downloaded from the CETRA website (http://www.kuleuven.be/cetra/Summer_School/applicationform.html). In addition to standard personal and academic information, applicants are also required to provide information on their research project, including the difficulties they have had and the questions they would like to discuss at the Summer School. CETRA usually informs candidates of whether their application has been accepted within two weeks of its submission.

As far as costs are concerned, the total enrolment fee is $€ 1,300$. This sum includes participation in all seminars and lectures comprised by the Summer School, accommodation at the university residence, breakfast, sandwich lunch, two shared dinners, as well as registration at the K.U. Leuven as a visiting scholar - which in turn enables one to access the library, computer facilities and wireless internet, and provides insurance. Staying at the university residence and having shared breakfast at the canteen is not mandatory, though giving them up will lead to a cost reduction of only $€ 19$ a day - which amounts to just over $€ 200$ all together - and indeed most Leuven hostels or hotels will cost far more than that. An advance of $€ 300$ must be transferred to the university account by late May, and the remaining $€ 1000$ must be paid by early July. Participants who cancel their registration can get their money back minus an administrative fee of $€ 200$.

Since the fees are extremely high and make participation particularly unlikely for students outside Europe, applying for a grant may be the best alternative. CETRA offers one grant of $€ 1,000$ every year. Applicants must send a brief explanation of why a grant is necessary. Furthermore, they must have been previously accepted by the CETRA board and must have paid a non-refundable advance of $€ 300$. EST (European Society for Translation Studies - http://www.est-translationstudies.org/) also offers a similar €1,000 grant to be spent on a Summer School in TS. The application process is similar to the one at CETRA and information about it is usually made available through its newsletter issued in May and November.

Once a student has been accepted, s/he will receive a letter of invitation as a visiting scholar, which is the key document for those who need to apply for a Schengen visa ${ }^{6}$. Brazilians do not need a visa to enter the EU (only a valid

\footnotetext{
${ }^{6}$ The term "Schengen" refers to a group of European countries that have abolished border controls between each other. Belgium and France, for instance, have signed the Schengen Agreement, whereas the UK has not. For more information on this, please check http://www.theschengenoffice.com/.
} 
passport), but for those nationals who do, the process must be started up to three months prior to departure at the local Belgian consulate or embassy. Regardless of the nationality of the students, they are granted the status of guest at the K.U. Leuven, which means they can have free access to the resources cited above. In addition to that, all students automatically receive accident and medical insurance for up to 3 months (6 months for EEA citizens). Detailed information about visas and insurance possibilities is provided in the brochure "Travelling to Leuven", which in turn is put together yearly by the K.U. Leuven and sent to all students upon registration.

\section{CETRA Summer School 2009: overview}

The 2009 edition of the CETRA Summer School took place between the $17^{\text {th }}$ and the $28^{\text {th }}$ of August, and the CETRA Professor was Martha Cheung, from the Hong Kong Baptist University. The following professors made up the teaching staff: José Lambert (K.U. Leuven), Andrew Chesterman (University of Helsinki), Dirk Delabastita (FUNDP Namur), Lieven D'hulst (K.U. Leuven), Peter Flynn (Lessius, Antwerp), Yves Gambier (University of Torku), Daniel Gile (ESIT, Université Paris 3 Sorbonne Nouvelle), Reine Meylaerts (K.U. Leuven), Franz Pöchhacker (University of Vienna), Christina Schäffner (Aston University), Maria Tymoczko (University of Massachusetts) and Luc Van Doorslaer (Lessius, Antwerp). Out of the 26 participants, 16 (or 61.5\%) attended European universities, whereas the other 10 participants visited universities in Japan (3 students, or 11.5\%), the USA ( 2 students, or $7.7 \%$ ), as well as South Korea, Nigeria, Algeria, Israel and India (1 student each, or 3.8\% $)^{7}$. As for their nationalities, 11 students (or 42.3\%) were from Europe; 6 (or 23.1\%) were East Asian; 3 were from the Near East (11.5\%); 2 (or 7.6\%) were from Africa and another 2 were from Latin America; India and the USA had one student (or 3.8\%) each.

As I had applied for the EST Summer School Grant (see section 2 above) and therefore needed to wait until I got a reply from them, my registration at the CETRA Summer School was somewhat delayed. I applied for the grant in early May and got their reply in early June. Only then did I make my first contacts at the K.U. Leuven, first with Reine Meylaerts, the director of CETRA, and then with Steven Dewallens, who is part of the administrative staff. Despite my delay, Meylaerts replied to my e-mail straight away, saying I would be more than welcome to take part in the Summer School. Since their deadline to apply for a visitor's card at the K.U. Leuven was the $12^{\text {th }}$ of June, they urged me to submit my registration as soon as possible. Dewallens also set up a login and password for a platform with some of the texts in the professors' reading lists, as well as with information about the other participants.

As regards financial matters, the EST Grant was directly transferred to CETRA, which means I only had to pay the difference (see section 2 above). Because I have a good friend who lives just outside Leuven, I did not need to

\footnotetext{
${ }^{7}$ See 3.6 below for more information on their research.
} 
stay at the university residence, nor did I intend to have breakfast at the university. For these reasons, a sum of $273 €$ (228€ for accommodation and $45 €$ for breakfast) was deducted from the total fee. In conclusion, I can say that the entire registration process went very quickly and smoothly, and that the staffs of both EST and of CETRA were extremely helpful, kind and efficient.

\subsection{A bit about Leuven}

Getting to Leuven - not to be mistaken with Louvain-la-Neuve, in Wallonia - is quite easy from within Europe, as the town is located just outside Brussels, with very good train and bus connections. From Brazil I believe one would have to change either in Paris or Amsterdam to Brussels. For the students who stay at the university residence, the university canteen and the building where the Summer School takes place are only a few meters away from each other. Although one can walk everywhere around the city centre, bicycles are undoubtedly the favourite means of transport of the locals. Tourists can rent bikes at different spots in the city.

Leuven is a charming little town filled with students and young people. The city is particularly lively in summer, when it gets a number of tourists from all over the world. It is also very conveniently located, only a couple of hours away by train from Bruges, Ghent and Antwerp, for example - short trips at the weekend are certainly a great idea. The city itself offers a wide variety of restaurants, pubs and shops - particularly bookshops. Speaking of books, the Central University Library (Universiteitsbibliotheek), situated a few hundred meters away from the Faculty of Arts (where the Summer School takes place), is most definitely worth a long visit.

\subsection{Arrival and impressions}

Students attending the CETRA Summer School are expected to register on the first day (Monday), when all briefings and opening speeches take place. Unfortunately I only managed to arrive on the second day, but as I had arranged everything with Meylaerts in advance, she kindly kept my "Welcome Kit" for me and repeated some of the most important information on Tuesday. Indeed, as far as the overall organisation of the event is concerned, I must say I was very impressed by the efficiency and kindness of everyone involved. Not once did they fail to inform us about the Summer School and our stay in Leuven. All events and activities took place as planned, and even though all students seemed extremely satisfied, the CETRA staff constantly asked us about whether we had any complaints or further requests.

Since I did not stay at the university residence, I cannot say anything about it. Nevertheless, I did hear from most students that the residence was indeed very comfortable and adequate. Concerning the meals, I had lunch at the university canteen every day and I also attended both dinners offered by CETRA. The sandwich lunch consisted of a variety of baguettes, juices and 
fruits, as well as coffee, tea and biscuits. As already mentioned (see section 1 above), the two dinners took place in a very nice restaurant located in the centre of Leuven, with a delicious three-course meal and many different drinks. The quality of the meals aside, however, I must admit that the best aspect of these collective meals was unquestionably the opportunity to mingle with the students and have agreeable, informal conversations with the professors. Indeed, it had never crossed my mind that I would one day have coffee with Andrew Chesterman - who, by the way, insisted to be called Andy - and discuss the weather conditions in the UK. I would even go as far as to say that, overall, this is the most valuable advantage of taking part in the CETRA Summer School. The engagement, interest and dedication of the professors involved are simply moving. One would probably think they would prefer to go to an expensive restaurant for lunch; or perhaps, if they attended the collective lunch at the canteen, one would imagine that they would only sit amongst themselves and have a well-deserved break from the students. Surprisingly, however, most professors not only had breakfast and lunch at university every day, but they also sat at different tables and made an effort to speak to different students every day - both about their projects and theses, and about trivialities.

In addition to this unique opportunity to have open conversations with some of the most important scholars in our field, I would say another key, incomparable advantage offered by the CETRA Summer School is the tutorials (see section 1 above). Indeed, being able to have a 30-minute session with every professor exclusively focusing on one's $\mathrm{PhD}$ thesis is a great privilege that brings a lot of insight into the research. I would certainly say that, in general, the tutorials brought the greatest number of contributions to my research, not only in terms of new references - which some professors even e-mailed me afterwards - but also in terms of new ideas and directions. In this sense, dealing with so many diverse suggestions at the same time may be rather conflicting and stressful as well (I shall write more about the specific feedback I got in 3.3 below). In any case, as doing $\mathrm{PhD}$ research is a rather lonely activity and feedback is scarce, the tutorials are indeed extremely advantageous.

\subsection{Feedback and my research}

As far as my research is concerned, I must say I was impressed by the overall interest shown by the professors. In very general terms, I am currently researching Translation Studies in Brazil, particularly in terms of the (lack of) impact post-structuralist thought has had in the field. During the tutorials, I had the chance to ask the professors about the relevance of my research, as well as about whether they themselves feel interested in both current Translation Studies in Brazil and post-structuralist thought in translation. Though to different degrees, all responses about Brazil were positive - most said that they find the Brazilian tradition fascinating, especially when it comes to translation (theory and practice); others mentioned more specific examples 
of Brazilian contributions to the field, including more widely recognized names in the international forum (such as Haroldo de Campos and Rosemary Arrojo) as well as of other renowned scholars who belong to the brazilian academia, such as Adriana Pagano, John Milton e Susanna Kampff Lages. Nevertheless, as for post-structuralist ideas in translation, nearly all professors claimed that they have little or no interest in this matter, and that poststructuralist thought has had no impact - or hardly any impact - on their research.

In this sense, despite their great interest in my research and willingness to help, I could not help noticing the contradiction inherent to the situation. On the one hand, all professors knew Arrojo's or Haroldo de Campos' work (at least to a certain extent) and had great admiration for them - though one or two admitted they never quite understood what Arrojo meant to say after all. On the other hand, none of them seemed to have any involvement whatsoever with post-structuralist thought. All in all, the only opinions they had about this matter - if any - were what I would call "Paulo Henriques Britto" kind of opinions; i.e. they would admit that Deconstruction, for example, made its minor contribution to the area a few decades ago, but does not have any great relevance to translation practice or does not raise any issues that are worth discussing (for Britto, please refer to BRITTO 1995 and 2001). What complicates the matter even further is the fact that most of these scholars perceive Brazilian Translation Studies as a field particularly marked by PostStructuralism, as its thinkers (for example, Campos and Arrojo, as already mentioned) seem to be the references that most often reach Europe.

Needless to say, this contradiction led to a great degree of confusion in my research, mainly because originally I intended to place more emphasis on Brazilian scholars whose theoretical affiliations (or affinities) lie with poststructuralist thought. After the Summer School, however, I felt both discouraged and encouraged to do so at once, and the implications here are indeed manifold. Their admiration for Brazilian scholars such as Arrojo motivated me to write more about Post-Structuralism and translation in Brazil, and so did the fact that many of these scholars seemed to have very little knowledge of post-structuralist trends. On the other hand, as many of them already knew Arrojo's work, but nevertheless felt in no way influenced by it (despite their interest and admiration), I felt like I should write about the so many other translation scholars in Brazil, who in turn have nothing do to with the post-structuralist tradition - and who, by the way, are the majority. For now, I can safely say that I am not yet out of the dilemma; nonetheless, I feel grateful and glad to have had the opportunity to learn about these professor's opinions and to have their precious advice.

\subsection{The 2009 CETRA Professor: Martha Cheung}

Writing about each of the 12 professors that made up the 2009 CETRA teaching staff would take up too much space, so I would rather simply include a note on the 2009 CETRA Professor, Martha Cheung. As already pointed out 
in section 1 above, Cheung held one lecture everyday during the first week of the Summer School. As expected, most of her lectures were dedicated to the Chinese translation tradition, following the recent publication of the volume An Anthology of Chinese Discourse on Translation, organised by Cheung (CHEUNG 2006). It would be impossible to briefly summarise the contents of all 5 lectures, but I can say they offered a broad overview of Chinese thinking and its relationship to Chinese translating - or theorising about it. Cheung stressed the (incidental) similarity between deconstructionist thought and the Chinese unconscious, which, unlike most of Western thought, is not dichotomic, but rather rooted in the yin and yang philosophy. This similarity, she claimed rather displeased, is often brought to her attention during her lectures outside China, when people frequently ask her whether Chinese scholars "have any theories of their own".

The Chinese professor also emphasised the importance of "the local" in Chinese tradition as a means to find "the other". Indeed, this question of whether Translation Studies should be more local as opposed to more global came up throughout the Summer School and the international conference ("The Known Unknowns of Translation Studies"8) that followed, with Chesterman ranking it amongst the most significant contemporary questions that translation scholars should try to answer. Quite predictably, Cheung was criticised for not advocating a global translation theory, applicable to the entire world, in and with the same terms. More than that, the guest professor was criticised for mentioning time and again the word "Chinese" - "Chinese mentality", "Chinese discourse", "Chinese translation", etc. - often being asked whether one cannot speak of translation in general terms, in spite of nationality, language or power. Cheung quite rightly replied that power and scholarship go hand in hand, as do nationality, translation and language, for example, hence her need to speak locally. In this sense, she was very critical of European and North-American hegemony, which, in her view, prevents European and North-American scholars to see beyond their own circles, thus trapping so-called "peripheral" theories. Undoubtedly, the fact that she was asked by CETRA to be their guest professor shows the openness of the European community to "the other"; however, judging by the criticism she got, one wonders how "open" the European community - or at least some of its members - actually was to her ideas.

\subsection{Seminars by the CETRA teaching staff}

The seminars held by the CETRA teaching staff were also very enlightening and diverse. The first lecture, by Andrew Chesterman, was entitled "What can Translation Research Learn from Darwin?". Inspired by

\footnotetext{
${ }^{8}$ This event took place at the K.U.Leuven between the $28^{\text {th }}$ and $29^{\text {th }}$ of August of 2009, and was organized as an international conference in honour of the twentieth anniversary of CETRA and Target (1989-2009). For more information on the event, please check http://www.kuleuven.be/cetra/anniversary/index.html.
} 
Darwin's 200th birthday, Chesterman looked for interesting aspects in the naturalist's research methods, and tried to apply them to our field. He stressed, for instance, that research is more emotional than rational, and that using subjectivity and analogies is positive in research. In addition to that, he pointed out that general knowledge - i.e. knowledge from other areas - may be very valuable to one's research, and that one must not necessarily develop new theories, but rather establish links and connections between already existing theories. Another element that called my attention was the fact that he emphasised the importance of accepting that taxonomy is fuzzy, and that nothing can be so exact and precise. One final idea he repeated throughout his seminar was the importance of using counter-arguments, as in a debate structure. He quite rightly pointed out that scholars must be able to anticipate counter-arguments to their ideas, and must therefore be able to deal with them.

The second seminar was held by Dirk Delabastita and was called "Status, Origin, Features. A Radically Open Concept of Translation". In his lecture, Delabastita basically advocated an international or global approach, claiming that Translation Studies must go through an "international turn" so as to become more scientific. Indeed, he - and many of the CETRA teachers seems to believe that local theories inevitably lead to a harmful fragmentation of the discipline, which in turn makes it less scientific. He also defended the concepts of "intention", "meaning" and "effect" as "crucial" for translation and translation theory, in spite of the fact that they have become increasingly "unfashionable" in the past few years. When I questioned him about how translation, being such a context and culture-specific activity, could possibly be approached in the very same way all over the world (very much in line with ARROJO [1992] 2003 and 1998), he replied that he would like to believe we have more in common than we think.

Christina Schäffner presented the seminar "Translation and Norms" on the next day. Her lecture was practically dedicated to Toury's ideas on translation norms, as tacit rules that govern the decision-making process in translation and as a strictly descriptive category. She advocated the study of translation norms so as to shed light on translation choices, translation culture and expectations in a given community and time, as well as the relevance of translation in a certain place and time. She, too, pointed to the need to find universal norms, i.e. common norms within different cultures. At the end of her seminar, I asked her about the "strictly descriptive" character of Descriptive Translation Studies, as this has always been my personal difficulty with DTS - and indeed most of the criticism it got concerns the same issue. As a translation student whose affinities lie with post-structuralist thought, I find it extremely difficult - if not impossible - to study so-called norms with "strictly descriptive" eyes, and to simply disregard the fact that this kind of study inevitably influences the researcher, thus leading to a different dynamics in the very establishment of norms. Schäffner, however, insisted that one can have "strictly descriptive" eyes and minds, and that neutrality is a perfectly achievable aim. 
Here I would like to interrupt the presentation of the lectures to make a brief remark on the preponderance of DTS as the theoretical framework most referred to during the Summer School. Gideon Toury's role in the foundation of both CETRA and Target - International Journal of Translation Studies was central, and so was his role in the establishment of Translation Studies as a discipline. I must confess, however, that I was a bit disappointed to hear about DTS time and again in the seminars of the Summer School and in the international conference that followed. However much I understand that Toury's contribution has been phenomenal, what disappoints me is not so much the fact that many contemporary scholars seem to have DTS as the key reference, but rather the fact that I did not hear Hans Vermeer's name once (only in the international conference during Nord's lecture). Indeed, in my opinion, Vermeer's (and his Skopostheorie) contribution was just as phenomenal, and yet his impact on the scholars present at the K.U. Leuven seems negligible. During the conference "The Known Unknowns of Translation Studies", Christiane Nord presented a lecture on the newer developments in the German Functional Approach. Although her lecture is now beside the point, what I want to mention is the fact that she was criticised at the end for the fact that the German Functional Approach is allegedly solely prescriptive and has not raised any hypotheses. Because I found this criticism irrelevant and unfair, I discussed it with her later, and she said that the same people who make this sort of criticism contradictorily use her books to teach their students and invite her to give lectures at their universities. This question still puzzles me, and unfortunately I have not come to a conclusion yet.

Discussing this issue with Mary Snell-Hornby, she explained to me that this "dominance" by DTS and the lack of interest in the German Functional Approach have a lot to do with the languages in which they were written, namely English and German respectively. Indeed, Snell-Hornby is very critical of the increasingly dominant role of English in academic discourse, particularly (and contradictorily) in Translation Studies. At the CETRA Summer School, for instance, everything had to be done in English. So there I was, spending two weeks with people from six different continents, and all I ever heard and spoke was English - even though the knowledge of English of many students and even professors was quite limited. At the last EST congress (in Ljubljana, in 2007) and at the international conference held in Leuven, in 2009, SnellHornby presented papers criticising this unnecessary dominance, and suggesting interesting alternatives which I strongly believe CETRA should consider adopting 9 . I cannot thoroughly discuss this here, but as Snell-Hornby puts it, multilingualism (at least three languages) amongst translation scholars should be a must, especially passive multilingualism. In this sense, lectures and papers in general should be accepted in languages other than English, and quotations from foreign languages should always be included before their

${ }^{9}$ The paper she gave at the 2007 Ljubljana congress is entitled "Is Translation Studies going AngloSaxon?

Critical comments on the globalization of a discipline" and will be published in March this year (2010). 
translations. This way, multilingualism would be encouraged rather than completely eliminated, as seems to be the case at these academic events.

But let us return to the CETRA Seminars. The fourth CETRA professor to present a seminar was Luc van Doorslaer. His lecture, entitled "Spreading Stereotypes through Media and Translation", offered a highly interesting overview of bias and leaning in Dutch newspapers. A recent study he conducted with his MA students has shown that Dutch newspapers have a very clear bias, revealed especially through their choice of news agencies. The study has also revealed that translations are often fully disregarded, with translated quotations and even entire texts being published as "original" texts. His students had the chance to speak to some of the editors of the newspapers investigated, who claimed that journalists are expected to do translations as a normal part of their job. Overall, I could not help noticing a negative tone when Doorslaer spoke of "bias" and "leaning" - particularly because he frequently said that newspapers should be more neutral and offer a more unbiased view of events. Unfortunately there was not enough time at the end of his lecture for me to ask him about it.

Peter Flynn presented the next lecture, entitled "Fieldwork in Translation Studies - Why not Ask them Yourself?" and José Lambert made a few comments at the end. Flynn described his $\mathrm{PhD}$ research, which was dedicated to Dutch translations of Irish poetry. He interviewed 13 Belgian and Dutch translators of Irish poetry so as to understand their views and to compare them to their actual work. His main aim was to put the translators in the spotlight, and also to investigate which values inform language, translation strategies and culture. He interestingly remarked that, in the future, translation theory will probably be propelled by translators, and not so much by so-called theorists.

"Are there Core Criteria for Good Scientific Work" was the name of Daniel Gile's lecture. Initially he discussed the main features of research in traditional sciences, and then went on to admit that most of these features do not apply to the Humanities, particularly not to Linguistics, Literature and Anthropology. Furthermore, he explained that much of the research done in Translation Studies is deliberately subjective, not empirical and rather prescriptive. Finally, he presented his 2 well-known paradigms in translation research, namely the "Liberal Arts Pole" (LAP) and the "Empirical Research Pole" (ERP), the former being more subjective and liberal, and the latter being stricter and thus closer to traditional sciences. Gile commented on the advantages and disadvantages of both, which can be summarised as follows: while on the one hand ERP is perceived as "superior" in TS for being closer to traditional science, on the other hand LAP can go further precisely because it is more flexible and because data can be marginal. In any case, he advised the students to decide whether their research is LAP or ERP, and admitted that cross-fertilisation might be rather fruitful, though unlikely, because within TS, there is too much competition between the two paradigms.

The penultimate seminar was presented by Yves Gambier and received the title "Metalanguage in TS: The Case of Translation Strategy". Similarly to most 
other professors, Gambier spoke of heterogeneity in TS as a problem, mostly blaming our "incoherent terminology" for our "incoherent science". Even though he admitted that translating is more of a local action than of a global action, he stressed that translation strategies are global, and that translation tactics, i.e. the steps through which a strategy is realised, can be local. In this sense, he spoke of macrostrategies and microstrategies, associated with strategies and tactics respectively. Furthermore, Gambier explained that strategies have a lot to do with routine, and that the main aim of translator training is to make their work more "automatised". Another interesting remark he made was that prescriptive work is not research. I do not quite understand how translators are to be trained without more "prescriptive" works, such as the ones by the German Functionalists. In any case, what I asked him at the end of his seminar was the same question I had asked Delabastita (see above), about how an action as diverse as translating should be approached in the exact same way all over the world. His answer, however, was the same as Delabastita's. I also wanted to ask him why he proposed yet new terms (strategies, macrostrategies, tactics, microstrategies) when he himself claims that we had better deal with the alleged "terminological chaos" in which we presently are, but unfortunately there was not enough time.

The last seminar, entitled "Research on Interpreting: What and How?" was held by Franz Pöchhacker. In his lecture he presented a thorough overview of research possibilities within Interpreting, including examples of theses and dissertations supervised by him. Pöchhacker's seminar must have been particularly interesting for students like me, who have little knowledge of the field of Interpreting, particularly in terms of research possibilities.

\subsection{Students' presentations}

The students' presentations of their research took place towards the end of the Summer School. As already mentioned above, most students had just started their $\mathrm{PhD}$, hence they did not have particularly much material to present. All of them, however, mentioned the area in which they are doing or intend to do research. Once again, since it would be impossible to analyse each and every student's research, I will simply list these areas here, more or less as they appear in the application forms. The most popular areas were Literary Translation (with 10 students, or 38.5\%) and Interpreting Studies (with 8 students, or $30.4 \%$ ), both with countless sub-areas (such as interpreter training, media interpreting, court interpreting, amongst many others). The 6 remaining students mentioned different areas, as follows: legal translation and intercultural studies (with 2 students each, or 7.7\%), as well as corpora studies, terminology, translation criticism and translator training (each with one student, or $3.8 \%$ ).

Needless to say, these areas are rather general and do not say much about the students' research projects. Nevertheless, my intention here is to simply offer the reader an overview of the most common research areas mentioned by the students. As I have already said above, the students' papers will soon be 
available on the CETRA webpage, and they will certainly provide more information on this matter.

However, one aspect that called my attention in general is the lack of interest, on the part of the students, in more theoretical research. Indeed, by analysing the participants' research questions, I have the impression that hardly anyone is concerned with theoretical matters; instead, they have very specific, "objective" questions they want to answer, and are in search of (or have already chosen) a theoretical framework to support them in their quest. This impression is, in fact, similar to the one I had when I started my MA in Translation Studies at the Universidade Federal de Santa Catarina (Federal University of Santa Catarina), Brazil, where nearly all students seemed to feel "obliged" to carry out some theoretical discussion in their dissertations, even though they themselves struggled to find a link between this discussion and their projects - which, in my year there, consisted mostly of annotated translations, translation criticism and corpora studies. Perhaps here one could speak of a trend, whereby students of TS resort to theoretical reflection once they already have "practical" research questions, instead of deriving research questions from theoretical reflection. This trend also seems to prevail at the University of Vienna, both at MA and at PhD level.

\section{Conclusion}

As I hope to have persuaded the reader, being a CETRA student is a unique experience I would recommend to every young scholar. The dialogue with the other students and professors brings tremendous contributions to one's research, not only in terms of new references, but particularly in terms of new ideas, feedback and criticism. I am convinced that those students who had the privilege to discuss their theses with a number of professors and other students from all over the world have a greater chance of succeeding in their academic endeavours. Indeed, this is the greatest advantage offered by the Summer School.

As far as the organisation of the event is concerned, I could not be more satisfied. I understand fees are extremely high - especially for non-EEA citizens - but attending the event is most definitely worth it. I would not change a thing concerning the programme and the overall structure of the event. I do believe, however, that the Summer School would be even more interesting if students and professors used languages other than English. I remember at one of the collective dinners, for instance, I was sat opposite Schäffner and Pöchhacker, and next to me were an Italian student and a Japanese student who spoke Italian. Schäffner, Pöchhacker and I spoke German, but shifted to English when talking with the other students. They spoke Italian amongst themselves, which although I could understand well, I could not speak well, hence I would usually reply in English. This kind of lively, spontaneous multilingual experience was, unfortunately, completely non-existent during the lectures, seminars and presentations, when many 
students and professors who do not have English as an active language felt uncomfortable and hardly encouraged to speak.

I must admit that the most pleasant surprise I had during the event was the interest and eagerness of the professors to learn about TS in Brazil. A couple of them even mentioned my thesis at the international conference that followed as a promising instance of new research in the field. If, on the one hand, their conflicting feedback got me rather confused, on the other hand, their enthusiasm about my research motivated me immensely. The negative surprise was undoubtedly the fact that DTS seemed to be "the" reference for most of the professors involved, rather than Vermeer or perhaps other newer scholars. Another negative surprise - though not entirely unexpected - was the fact that not a single professor or student had any interest in poststructuralist thought in translation. Indeed, during the Summer School, I was the only one to ever mention anything along these lines. Nevertheless, during the conference that followed the Summer School, Anthony Pym spoke about this issue (i.e. the lack of interest in Deconstruction in Europe) as a "historical conflict" and as a "main problem" with which "we" will have to deal at some point.

I left Leuven with far more questions than when I arrived. I would like to end this paper with some of these questions as suggestions for future works and reflections, perhaps? (i) Why is the influence of Post-Structuralism somewhat strong in (Latin) America - and in different terms in China, too and so negligible in Europe? (ii) Why does nearly everyone speak of Toury's concepts and not of Fish's "interpretive communities" (see FISH 1980)? (iii) Would local research (as defended by RODRIGUES 1999, for instance) in TS be similar to the highly specific research we find in linguistics, for example, where 400-page theses are written on the pronunciation of a given phoneme in, say, the northern area of a town? (iv)Must one have a political agenda when writing a thesis? (v) Has post-modern reflection left "us" with nothing but socalled "constraints" and "problems"? In other words, can human limitations not be perceived as "natural" and simply "human", rather than as obstacles to be transposed by "true" science? (vi) Is this really the most post-structuralist reflection will achieve in TS, i.e. people will carry on using their structuralist concepts normally, though slightly more critically? 


\section{References}

ARROJO, Rosemary (Org.) [1992]: O Signo Desconstruído: Implicações para a tradução, a leitura e o ensino. 1. Campinas, Pontes, 2003.

: 'The Revision of the Traditional Gap between Theory and Practice and the Empowerment of Translation in Postmodern Times'. In: The Translator - Studies in Intercultural Communication. Manchester, England, v. 4, n. 1, p. 2549, 1998.

BRITTO, Paulo H.: 'Lícidas: diálogo mais ou menos platônico em torno de 'Como reconhecer um poema ao vê-lo', de Stanley Fish'. PaLavra (PUCRJ), Rio de Janeiro, v. 3, 1995, p. 142-150.

: 'Desconstruir para quê'. In: Cadernos de Tradução VIII. Florianópolis, UFSC, 2001, p. 41-50.

CHEUNG, Martha P. Y.: An Anthology of Chinese Discourse on Translation, Volume 1: From Earliest Times to the Buddhist project. Manchester, St Jerome Publishing, 2006.

FISH, Stanley: Is There a Text in this Class? - The Authority of Interpretive Communities. Massachusetts, Harvard University Press, 1980.

RODRIGUES, Cristina Carneiro: Tradução e Diferença. São Paulo, UNESP, 1999.

SNELL-HORNBY, Mary: 'Is Translation Studies going Anglo-Saxon? Critical comments on the globalization of a discipline'. In: Why Translation Studies Matters (org. Daniel Gile et al). Amsterdam, John Benjamins, March 2010. 